\title{
SELECTION OF POUR POINT DEPRESSANTS FOR TODAYS ENGINE OILS INCLUDING AGING IN THE PRESENCE OF BIODIESEL BY CEC L-105
}

\begin{abstract}
All mineral derived base stocks used in lubricants contain waxy hydrocarbons that come out of solution when temperature decreases. They can form a threedimensional wax crystal network that can totally immobilise the oil. In formulated engine oils some additives have a "waxy" or crystalline structure and further contribute to the formation of a crystal network that impairs oil flow. Waxiness is evidenced at low temperature by higher pour-point, yield stress and viscosity compared to a wax free oil. Inadequate oil flow to critical parts of the equipment may result in costly failures. The function of Pour-Point Depressant (PPD) is given in the name. They depress pour-point by inhibiting the waxy structures that form in mineral oil at low temperature. But for modern engine oils pour-point has little relevance and isn't included in modern international engine oil standards. Industry experience over the decades has replaced pour-point by other more valid assessments of an engine oil's suitability at low temperature. In particular low temperature pumpability by Mini Rotary Viscometer (MRV) due to its inclusion in SAE J300 specification is the primary test. In some cases this is now required on used oil, and most recently in Europe on oil oxidised in the presence of biodiesel by CEC-L-105-12. However PPDs exist or have been developed which are effective in these evolved low temperature requirements of engine oils.

In this paper we show that PPDs are available which are effective against this latest European CEC L-105 requirement, although extra consideration must be given to their selection. We also show that multiple low temperature requirements tend to narrow the choice of acceptable PPDs, and the choice of PPD can be strongly influenced by the presence of other additives in addition to the mineral oil. These combined with the extra requirement for CEC L-105 has made PPD selection more difficult, but based on our work reported here this new challenge can be met by correct PPD selection.
\end{abstract}

Key words: PPD (pour point depressant), engine oils, gear oils, oil aging, method CEC L-105-12 


\title{
IZBOR ADITIVA ZA SNIŽAVANJE TECIŠTA ZA DANAŠNJA MOTORNA ULJA UKLJUČUJUĆI STARENJE U PRISUTNOSTI BIODIZELA METODOM CEC L-105
}

\begin{abstract}
Sažetak
Sve vrste mineralnih baznih ulja koje se koriste u mazivima sadrže parafinske voskove koji se sniženjem temperature talože iz otopine. Oni mogu stvoriti trodimenzionalnu mrežu kristala voska koja pak može u potpunosti imobilizirati ulje. Neki aditivi u formuliranim motornim uljima imaju "voskastu" ili kristalnu strukturu koja dodatno doprinosi formiranju kristalne mreže koja ometa tečenje ulja. Voskasta struktura očituje se višim tecištem, većim smičnim naprezanjem koje sprečava tečenje ulja $i$ višom viskoznošću pri niskim temperaturama u odnosu na ulja bez voskastih parafinskih ugljikovodika. Neprikladan protok ulja do kritičnih dijelova opreme može dovesti do skupih kvarova. Negativni učinci pisutnosti ovih voskastih struktura najčešće se kontroliraju korištenjem aditiva za snižavanje tecišta (PPD). Izbor prikladnog PPD-a ovisi o brojnim čimbenicima. To uključuje vrstu aditiva, brzinu njegovog dodavanja, vrstu korištenog baznog ulja, utjecaj drugih aditiva $i$ različitih brzina hlađenja $i$ brzina smicanja kojima je ulje izloženo u primjeni. Osim toga, povećana upotreba baznih ulja više API grupe znatno utječe na osnovnu strukturu tekućine u kojoj se ti voskovi stvaraju, a time i na izbor odgovarajućeg depresanta tecišta. To znači da izbor odgovarajućeg PPD-a postaje veliki izazov.
\end{abstract}

Ključne riječi: aditiv za snižavanje tecišta, motorna ulja, zupčanička ulja, starenje ulja, metoda CEC L-105-12

\section{Introduction}

All mineral derived base stocks used in lubricants contain waxy hydrocarbons that come out of solution when temperature decreases. They can form a threedimensional wax crystal network that can totally immobilise the oil. Such waxiness has long been recognised in mineral oils and formulated fluids and most familiarly described by pour-point. Pour-Point Depressants (PPDs) were originally conceived as additives to depress pour-point. However, it has long been recognised that pourpoint testing does little to describe the low temperature acceptability of modern formulated engine oils. In fact international standards covering such do not include pour-point, although it is still included in many industrial lubricant requirements. Low temperature pumpability testing, which incorporates Yield Stress and Apparent Viscosity aspects, has long been a part of SAE J300 to ensure adequate oil flow to critical parts of the engine. More recently low temperature testing has been extended to used oils, and also for oil aged in the presence of biodiesel fuel as both of these have been found to influence low temperature acceptability beyond that described by testing of the fresh oil. In used oil the solvent environment in which the wax structure forms is significantly altered and also biofuel contamination can introduce new wax species to the oil. 
Similarly, the increased use of higher API group base-oils has brought changes to the solvent environment in which the wax structure is forming. Some of the additives used in formulated engine oils have a "waxy" or crystalline structure and further contribute to the formation of a crystal network that impairs oil flow. All these factors combined mean the role of the PPD has moved way beyond the original brief of improving pour-point by controlling fresh base-oil derived waxy structures. The new requirement to meet low temperature pumpability performance after aging in the presence of biodiesel is the latest in a string of additional requirements that has complicated PPD selection and narrowed the range of acceptable PPD candidates. The result is that the selection of a suitable PPD is becoming increasingly challenging, but work reported here indicates PPDs capable of meeting the latest challenge of CEC-L-105 biodiesel oxidation ageing are available.

\section{Historical context to current engine oil low temperature requirements}

Early lubricants were mineral oils refined from petroleum stocks with few or no additives. It was recognised that the linear hydrocarbons naturally present in the base-oil could crystallise at low temperature and immobilise the oil seriously compromising its performance as a lubricant. The pour-point test procedure, which has its origins back in the 1890's and is the forerunner of the current ASTM D97 procedure, was the first attempt to qualify oils in respect of their low temperature usefulness. All pour-point procedures follow a similar principle; a specimen is cooled inside a cooling bath to allow the formation of paraffin wax crystals, and then tilted or similarly disturbed to check for surface movement. The lowest temperature at which flow is still observed is recorded as the pour-point.

The desire to improve pour-point, and so expand the oils lubricating range to lower temperatures, dates back to those early days. Prior to the 1930s, the options for improving pour-point were very limited. Dilution with kerosene was used to increase the solvency and so better dissolve the waxes at low temperature but this also decreased the viscosity at high temperature. Addition of asphaltic resins or microcrystalline waxes derived from the refinery process also had some effectiveness. In the 1930's alkylated naphthalenes then later polyalkyl methacrylates (PAMAs) based on waxy alkyl groups were found to be increasingly effective in improving pour-point, and became known as Pour-Point Depressants (PPDs).

Throughout this time and later, pour-point was the primary measure of a lubricant's low temperature efficacy. Internationally engine oils followed the SAE J300 specification which included the Cold Cranking Simulator (CCS) test as the sole check on low temperature performance. The CCS test, which measures low temperature high shear viscosity, was designed to predict the resistance to startability due to the viscosity of the oil film on the engine crankshaft. This dates from early problems with starting engines in cold weather [1]. As such the CCS test uses relatively high shearing rates and rapid cooling and so even though wax is crystallised it does not form a destructive network that traps the oil. 
Such networks are formed under slower cooling and more settled, near zero shear conditions as might be found in the sump of a parked engine. As PPDs inhibit only the wax structure network rather than the quantity of wax precipitated they have no influence on the CCS test, beyond that expected for a small addition of viscous polymer. It was only after the startability problems addressed by the CCS test were solved that the more insidious problem of oil pumpability was recognised following field failures. A number of studies [2], many under the auspices of ASTM, showed certain cooling profiles over extended times could encourage waxy structures to form and cause pumpability failures. Two distinct failure modes were identified [5], Air Binding where the oil mass is gelled and an air channel forms through it to the oil pump inlet, and Flow Limiting where the viscosity is too high to allow sufficient oil flow to the critical engine parts. These studies led to pumpability being introduced into SAE J300 and evaluated via ASTM D4684. It was by now widely accepted that Pour-Point, CCS and other low temperature tests didn't predict an oil's tendency to pumpability failure, and studies exist which directly demonstrate such [3],[4].

The cooling profile used to determine pumpability by Mini Rotary Viscometer (MRV) as described by ASTM D4684 is run for approximately 2 days (actual time dependant on the SAE J300 "W" grade) and has a cooling rate of $0.33^{\circ} \mathrm{C}$ per hour through the critical crystallisation temperature range of $-5{ }^{\circ} \mathrm{C}$ to $-20{ }^{\circ} \mathrm{C}$. This cooling profile is often referred to as TP-1 and is the critical aspect of this test. It was determined after investigation of climatic data from various geographical locations during field pumpability failures in Northern USA during the winter of 1981/82 [6]. ASTM D4684 replaces the earlier pumpability test ASTM D3829 which failed to predict the 1981 winter field pumpability failures despite having an already quite lengthy16 hour cooling profile [7],[8],[9].

Oils which pass pumpability requirements as fresh oil can still give pumpability failures when the oil has been aged in an engine. Identified by Bartko et al. [10], oils in an oxidised state exhibited pumpability failures by either the air binding (Yield Stress) or Viscosity aspect of the ASTM D4684 MRV TP-1 procedure even though other rheological properties such as CCS or kinematic viscosity were not necessarily excessively high. The recognition that oxidised oil could lead to pumpability failures and also increase viscosity that could detriment fuel efficiency lead to the introduction of used oil pumpability limits in the ILSAC GF-4 specification [11]. In ILSAC GF-4, ASTM D4684 pumpability performance has to be met on used oil sampled after completion of the Sequence IIIGA engine test.

Work by Evonik Oil Additives [12] showed that PPD could greatly assist in achieving the used oil pumpability performance requirement after both Sequence IIIGA and field taxi fleet aging. Importantly, it was also demonstrated that the PPD was not degraded by either Sequence IIIGA or taxi fleet aging. This meant oil-less-PPD could be aged in the engine and then the correct PPD determined by studies on that used oil, the results from such a study essentially being equivalent to adding the PPD to the oil before engine aging. Following from this, the ROBO test was developed by Evonik as a Sequence IIIGA screener [13]. 
This now meant that aged oil could be qualified after a relatively simple bench test, or aged-oil-less-PPD generated to allow a study to select the correct PPD type and treat rate without the significant extra expense of a Sequence IIIGA engine run. The ROBO test was incorporated into the ILSAC GF-5 specification as an alternative to Sequence IIIGA engine test [14]. Most recently the influence of biodiesel on pumpability has been an industry concern. Oil contaminated with biodiesel and then aged has the potential to behave differently from uncontaminated oil in terms of PPD appetite due to the different oxidisable species and also the introduction of new wax like species from the biodiesel. Discussion of this is the main focus of this paper and revisited in a later section.

\section{Factors influencing PPD choice and adequate low temperature behaviour}

As mentioned, over time additional testing requirements have been added to engine oils. While pour-point was an early cold flow test, it is not included in SAE J300 where the requirement which dominates PPD choice is the MRV TP-1 pumpability (ASTM D4684). For grades also targeting the ILSAC GF-5 specification there is an additional requirement for Gelation Index in the Scanning Brookfield (ASTM D5133) test. Also for ILSAC GF-5, MRV TP-1 pumpability after aging by ROBO or Sequence IIIGA is a requirement, and a number of ACEA grades now require MRV TP-1 pumpability after aging in the presence of biodiesel by CEC L-105. The significance of these additional test requirements is that each test has its own PPD appetite and there may be little overlap of acceptable PPD candidates determined for each test. For an oil evaluated by one low temperature test a number of acceptable PPDs will be identified. This number may be quite high or low depending on the test severity and the quality of base oils and components in the oil. So an oil may be regarded as either "easy" or "difficult" depending on the number of PPDs that allow a test pass in addition to the required PPD treat rate. For a second low temperature test performed on the same oil a number of acceptable PPDs will again likely be found, but most often this new PPD list will not be the same as that found for the first test. As discussed below the PPD requirements by one cold test do not provide a reliable indicator of optimum PPD when a different test is used. So continue to add extra low temperature test requirements and it can be seen that the number of acceptable PPDs that will meet all test requirements is likely to dwindle, and PPD treatment level likely to increase.

An example of this is shown in Figure 1 for an engine oil requiring both MRV TP-1 and the Scanning Brookfield Gelation Index performance. All testing met the MRV TP-1 Viscosity requirement (of $60000 \mathrm{mPas}$ maximum) so the diagram below (figure 1) shows only the Yield Stress by MRV TP-1 and the Scanning Brookfield Gelation Index where the requirements are $35 \mathrm{~Pa}$ and 12 maximum respectively. It can be seen that PPD 1 and PPD 2 are acceptable in one test, but not the other, showing that the performance of a PPD in the Gelation Index test is not a reliable indicator of performance in the MRV test, and vice versa. 
In general it is found that low temperature test performance cannot be predicted from the performance in a different low temperature test despite using the same oil. So in this example each individual test has two or three acceptable PPDs, but for both test requirements combined only one PPD is acceptable, PPD 4. The MRV TP1 and the Scanning Brookfield tests are showing different appetites because of their different cooling profiles and shear rates.

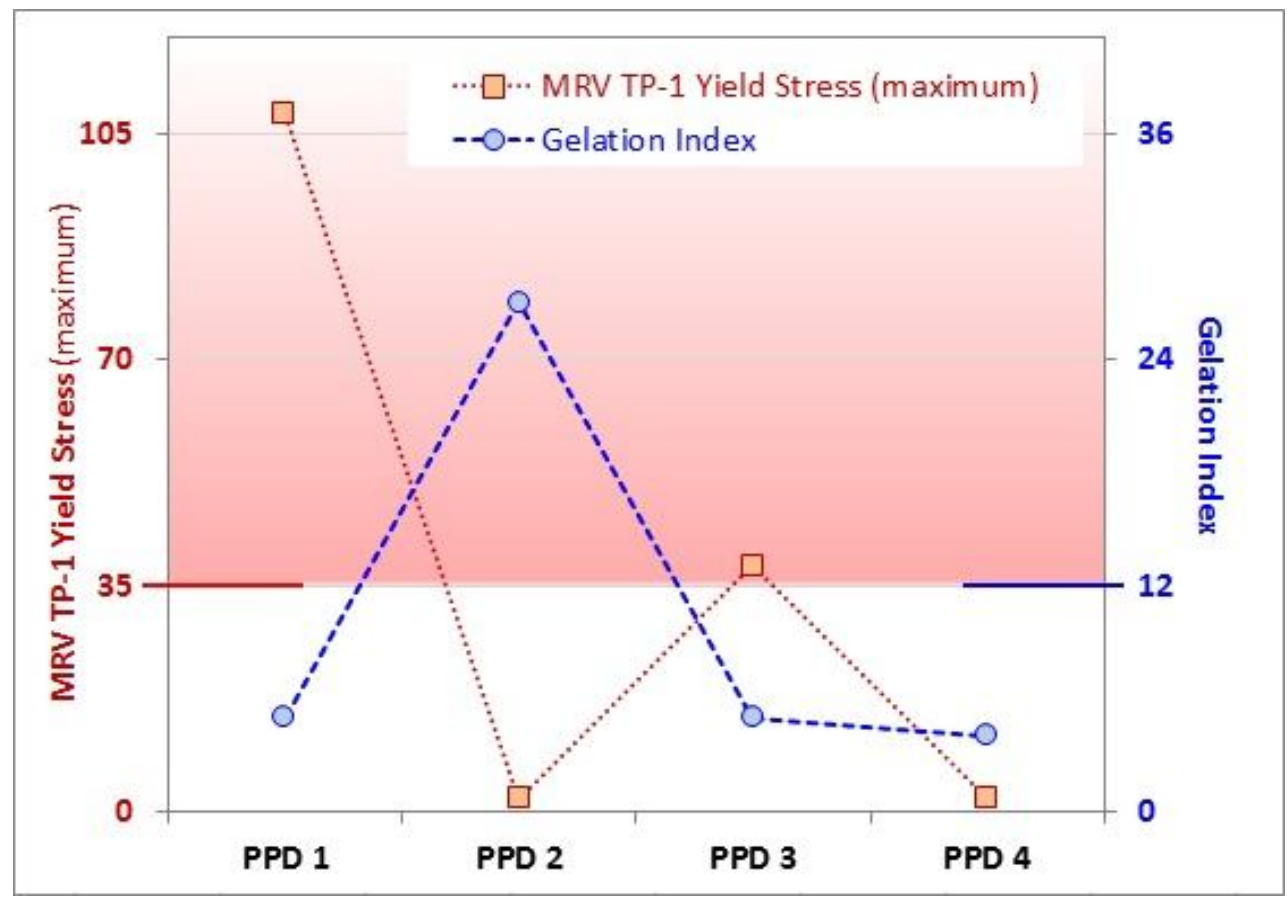

Figure 1: Effect of PPD selection on the oil Yield Stress (in Pa) in the MRV TP-1 and on Gelation Index in the Scanning Brookfield

A further example follows, and shows that low temperature testing requirements of a finished formulation do not necessarily coincide with the low temperature responses of the base-oils employed even though base-oil is normally assumed to be the dominant influence as the predominant source of waxes.

Different grades of group I type base-oil from the same refinery source were tested for pour-point after addition of two candidate PPDs with results shown in Figure 2. It can be seen that in this study there was overall performance advantage for PPD B over PPD A. These same three base-oils were used to formulate a range of fully formulated engine grades as shown in the Table 1. Each oil was evaluated by MRV TP-1 as required by SAE J300 with the results indicated. 


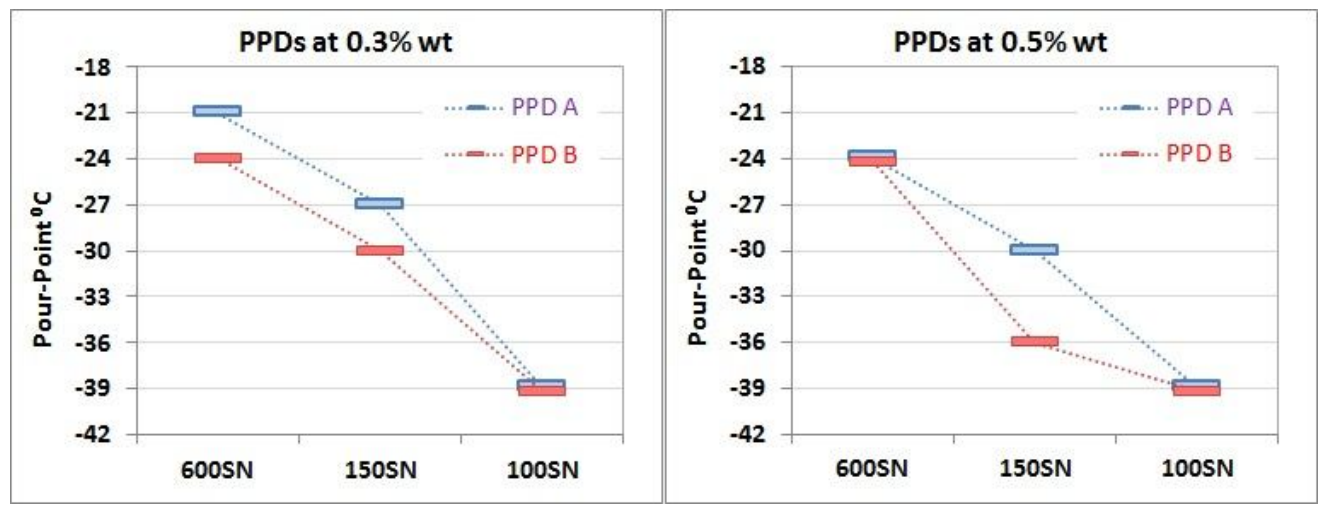

Figure 2: Pour-Point for PPD A \& B tested at $0.3 \%$ and $0.5 \%$ in group I source 100SN, 150SN, 600SN

Table 1: MRV TP-1 testing for PPD A \& B tested at $(0.3 \%$ and $) 0.5 \%$ in engine oils based on the same group I source 100SN, 150SN, 600SN.

\begin{tabular}{|l|c|c|c|c|c|c|}
\cline { 2 - 7 } \multicolumn{1}{c|}{} & $\begin{array}{c}\mathbf{5 W}-30 \\
\text { PCMO }\end{array}$ & $\begin{array}{c}10 \mathrm{~W}-30 \\
\text { PCMO 1 }\end{array}$ & $\begin{array}{c}10 \mathrm{~W}-30 \\
\text { PCMO 2 }\end{array}$ & $\begin{array}{c}10 \mathrm{~W}-40 \\
\text { HDEO 1 }\end{array}$ & $\begin{array}{c}10 \mathrm{~W}-40 \\
\text { HDEO 2 }\end{array}$ & $\mathbf{2 0 W}-50$ \\
\hline PPD A & pass & pass & pass & pass & pass & pass \\
\hline PPD B & pass & fail & fail & $\begin{array}{c}\text { borderline } \\
\text { pass }\end{array}$ & pass & pass \\
\hline
\end{tabular}

Here PPD A was found to be the better of the two PPD options and the only one giving a pass in all oils despite the preference for PPD $B$ in the base-oil study. This again suggests results from one low temperature test are a poor predictor of results in a different low temperature test, but mainly show that performance in the component base-oils is not a reliable indicator of the PPDs performance in the fully formulated fluid. In the fluid exampled here the VII type was an OCP exhibiting crystallinity in the MRV TP-1 test and this was tending to dominate the PPD appetite. PPD type A was more effective at inhibiting waxy structures from this base-oil plus VII combination.

The additional requirements to maintain MRV TP-1 pumpability after ROBO (ASTM D7528) or biodiesel fuel contamination aging (CEC L-105) will further complicate PPD selection. A reduction in the number of working PPD options is possible, if not likely. The influence of aging in the presence of biodiesel is discussed in a later section but here we show an example of a $5 \mathrm{~W}-30$ oil where aging by ROBO has influenced the PPD appetite. Three PPDs were evaluated at $0.3 \%$ in a $5 \mathrm{~W}-30$ oil. The PPD was added to the oil fresh and after the ROBO test. During the ROBO test the oil showed a strong resistance to oxidation with a weight loss of $40 \%$ (figure 3 ). 
All PPDs are giving good results in the fresh oil but only one of them, PPD 3, is giving passing MRV TP-1 results in the aged oil. A further two $5 \mathrm{~W}-30$ oils were formulated with the same VI, DI and PPD. They only differ by the source of the Group II oil that was used. A PPD was added at $0.5 \%$ in the fresh and aged oils. It performed well in the fresh oils in MRV TP- 1 at $-35^{\circ} \mathrm{C}$ but failed at $-30^{\circ} \mathrm{C}$ in one of the aged oil with a Yield Stress of $70 \mathrm{~Pa}$ (figure 4).

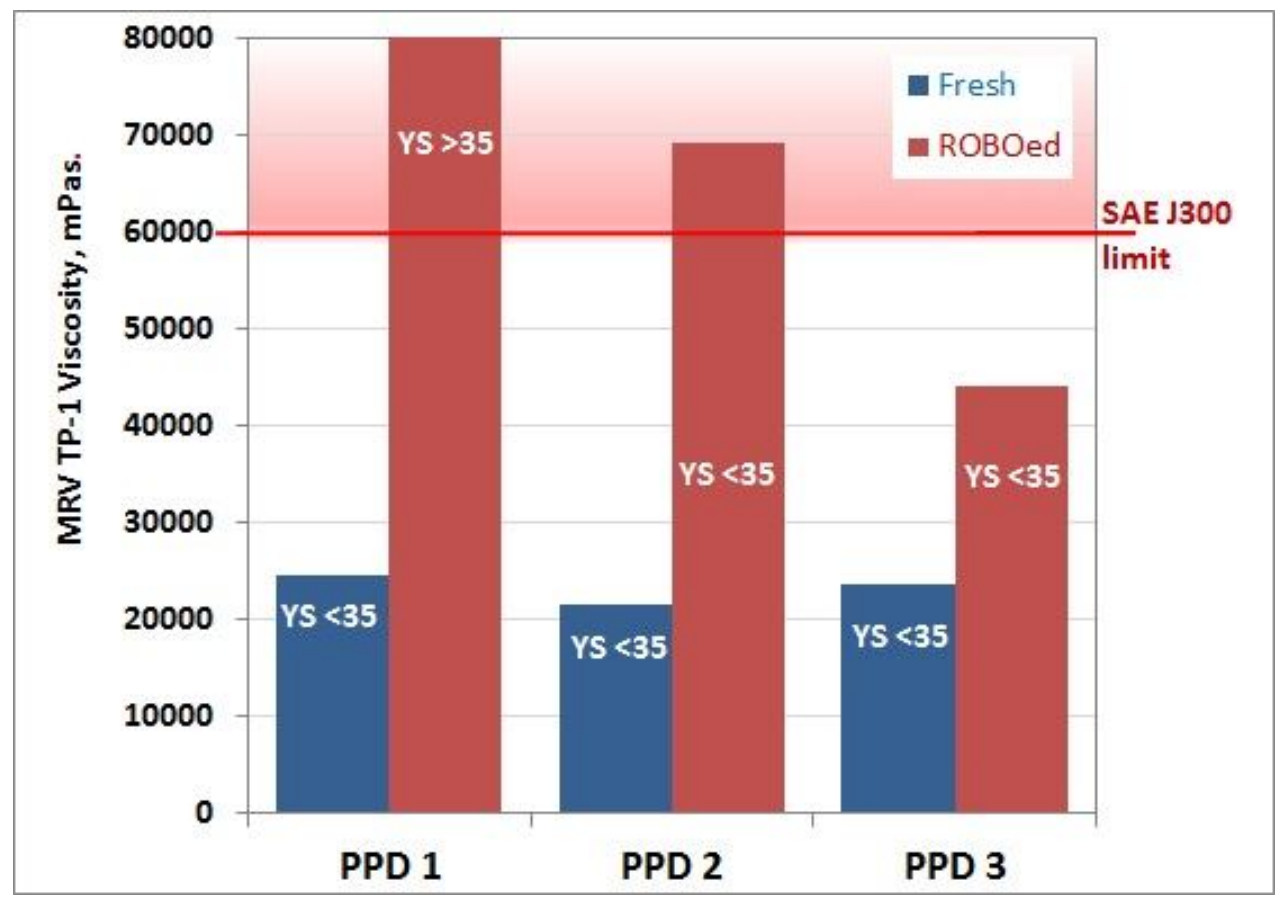

Figure 3: MRV TP-1 Viscosity at -35 and $-30{ }^{\circ} \mathrm{C}$ for the fresh and aged $5 \mathrm{~W}-30$ oil respectively

In conclusion for this section it can be seen that increasing the number of low temperature tests will make the search for a suitable PPD more complicated, and potentially reduce the number of acceptable PPD candidates. Different test types and other formulation components influence the PPD appetite so it is important to work on the actual finished formulation, less PPD, in any PPD selection study. Further complications arise due to the requirements to meet different viscosity grades of a product line, as well as requirements across product lines where a lubricant blender who will want to minimize the number of PPDs he needs to stock. While it would be possible to define an optimum PPD for every lubricant, this is obviously not practical. It is unusual that a single, universal PPD would be optimum for all of the products in a blend plant. 
However, one PPD will sometimes meet all of the needs with a modest up-treat in a few products. The blender must weigh this option against the logistics issues.

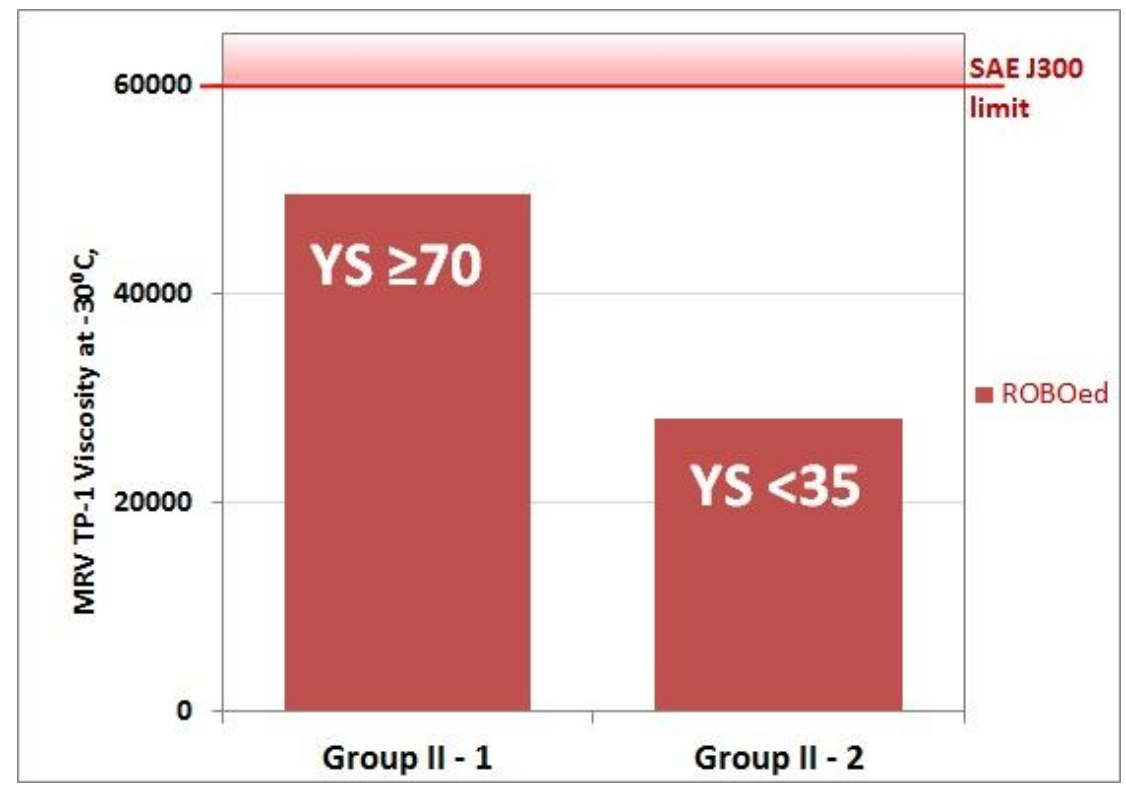

Figure 4: Effect of Group II source on MRV TP-1 after the ROBO test

\section{PPD treat rate and reversion}

As mentioned, the trend of modern engine oils to have a number of different low temperature tests influencing PPD choice has tended to reduce the number of PPDs that will be found acceptable. However, a non-optimum PPD can still sometimes be found to be suitable if used at a higher treatment level and as mentioned such a strategy is often needed by a lubricant blend plant to avoid a proliferation of the number of PPDs used. This approach does not always work. Sometimes a poorly selected PPD will never work whatever treat rate is used. Or the performance is so marginal that the passing result may not remain so in future production blends as subtle component quality changes take place over time. It is therefore prudent to extend any PPD selection study to look at the oils response to a range of PPD treatment levels. This ensures the most robust and economic treatment level is selected and also will help gauge the likely robustness of the formulation to future component quality drift and other factors. It's easy to visualise that a formulation can fail to meet low temperature requirements due to insufficient PPD, but what is less well recognised is that formulations can also fail when too much PPD is added. This effect is known as PPD "reversion". In addition if the range of acceptable PPD treatment level is narrow before reversion occurs that is an indication of low formulation robustness. 
To interact with waxy structures and inhibit them as they form at low temperature the PPD itself must possess some wax-like character. Addition of PPD therefore increases the overall waxiness of the oil. At low PPD treat rates this increase in waxiness is not apparent as wax structure is being reduced even as "wax" content due to the PPD is increasing. However, as PPD treat rate is increased the benefit due to the PPD reduces, and eventually a treatment level of PPD is reached when no further inhibition of the waxy cold structure takes place. Addition of PPD beyond this point can therefore see a reversal of the benefit brought by the PPD due to the overall increase in wax species in the oil. This can manifest itself as a worsening of pour-point, or increase in low temperature viscosity of the oil, and is counter to the effect of the PPD at lower treats hence the name "reversion". With PPDs more is not always better (figure 5).

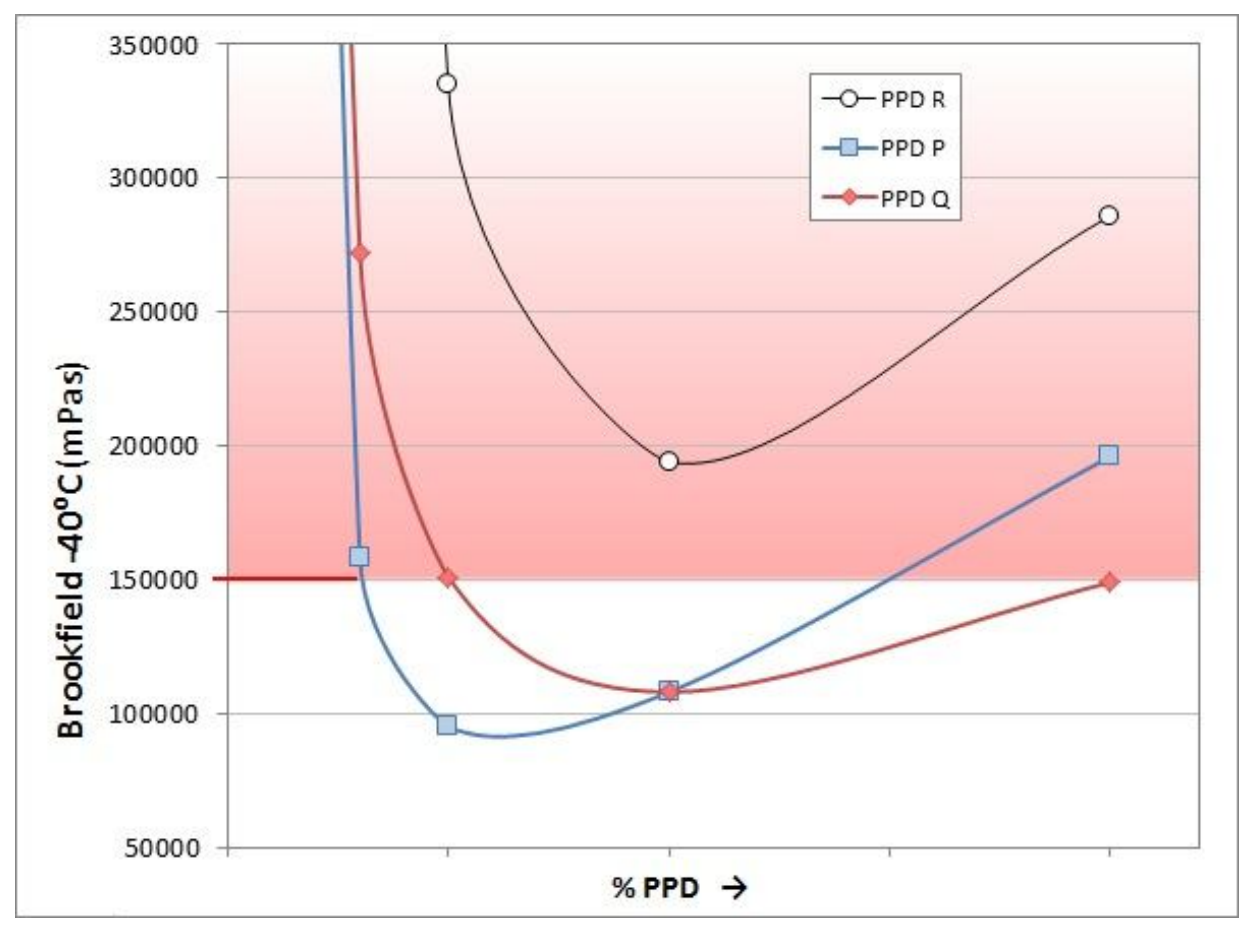

Figure 5: Dinamic viscosity (in mPas) (Brookfieldmethod) at $-40{ }^{\circ} \mathrm{C}$ versus $\%$ PPD for a $75 \mathrm{~W}$-90 gear oil for a PPD treated to achieve $<150000 \mathrm{mPas}$

There are many influences on the point at which reversion occurs. Lower solubility base-oils with high additive loading and tested at very low temperatures will have an increased risk for reversion and for the reversion effect to be sharper and happening at lower addition levels of PPD. The type of the PPD is also a strong influence; a less suitable PPD choice can often show the strongest reversion tendencies. 
As mentioned, formulations with a strong reversion tendency and a narrow range of acceptable PPD treat rates are likely to be less robust.

Sometimes other additives such as detergent or VII in the oil can be waxy. In these cases it is possible for some PPDs to revert at relatively low treatment rates. However the wax activity from such other additives is relatively narrow, and it's often possible to select a PPD candidate which minimises the reversion risk, or can even work to inhibit the structures forming due to the waxy additive.

\section{Biodiesel fuel contamination}

The influence of biofuel contamination on the operability of engine oil has been a concern since the introduction of a mandatory biofuel component in fuel in many regions. In Europe, ACEA has introduced the CEC L-105-12 test to confirm acceptable Low Temperature Pumpability of engine oils when aged in the presence of biodiesel contamination. This test is now included in all ACEA heavy duty categories and in all light duty categories except A3/B3. The CEC L-105 test describes a method to produce an aged oil that has similar characteristics to failing used oils from the field. Using standard lab glassware, $250 \mathrm{~g}$ of the oil sample contaminated with $5 \%$ biodiesel is aged in the presence of an iron compound catalyst for 72 hours at $150{ }^{\circ} \mathrm{C}$ and $10 \mathrm{l} / \mathrm{h}$ of air flow. Low Temperature Pumpability on this aged oil is determined by the well-established MRV TP-1 method ASTM D4684.

Table 2: PPD performance by MRV TP-1 in a 15W-40 engine oil before and after CEC L-105 aging

\begin{tabular}{|c|c|c|c|c|c|c|}
\hline & \multirow{2}{*}{$\begin{array}{r}\text { PPD W } \\
0.2 \%\end{array}$} & \multirow{2}{*}{$\begin{array}{r}\text { PPD X } \\
0.2 \%\end{array}$} & \multirow{2}{*}{$\begin{array}{r}\text { PPD Y } \\
0.2 \% \\
\end{array}$} & \multirow{3}{*}{$\begin{array}{r}\text { PPD Z } \\
0.2 \% \\
\end{array}$} \\
\hline & & & & & & \\
\hline \multirow{3}{*}{ Fresh Oil } & \multirow{3}{*}{$\begin{array}{l}\text { MRV TP-1 } \\
\left(15 W,-25^{\circ} \mathrm{C}\right) \\
\text { ASTM D4684 }\end{array}$} & & & & & \\
\hline & & [mPa s] & fail & pass & pass & pass \\
\hline & & Yield Stress [Pa] & fail & pass & pass & pass \\
\hline \multirow{3}{*}{$\begin{array}{l}\text { Oil after } \\
\text { CEC L-105 }\end{array}$} & \multicolumn{2}{|r|}{ PPD wt $\%$} & $0.2 \%$ & $1.0 \%$ & $0.5 \%$ & $0.2 \%$ \\
\hline & \multirow{2}{*}{$\begin{array}{l}\text { MRV TP-1 } \\
\left(15 W,-25^{\circ} \mathrm{C}\right) \\
\text { ASTM D4684 }\end{array}$} & $\begin{array}{l}\text { Apparent Viscosity } \\
\text { [mPa s] }\end{array}$ & Bad fail & pass & fail & pass \\
\hline & & Yield Stress [Pa] & Bad fail & fail & fail & pass \\
\hline
\end{tabular}

Subjecting an oil to CEC L-105 oxidation can cause MRV TP-1 pumpability failure either by an increase in the Apparent Viscosity, or Yield Stress, or both. In all these cases a more careful selection of the PPD candidate can prevent the failure. For example, shown in Table 2 is a commercial $15 \mathrm{~W}-40$ engine oil normally formulated with $0.2 \%$ of a commercial PPD. A study to select a suitable PPD looked at four PAMA type commercial PPDs in the fresh oil-less-PPD and showed the oil relatively easy to treat in terms of passing the MRV TP- $1-25{ }^{\circ} \mathrm{C}$ pumpability requirement of SAE J300. Only one PPD, PPD W, was found unsuitable at $0.2 \%$ treat rate. After aging in the CEC L-105 test, the oil became more difficult to treat. PPD types X \& Y were now found unacceptable, even at increased treat rate. PPD $Z$ did however still provide a passing result without an increase to the $0.2 \%$ treat rate. 
A further example is a $5 \mathrm{~W}-30$ engine oil treated at $0.3 \%$ with a range of commercial PAMA type PPDs and again tested by MRV TP -1 at $-35^{\circ} \mathrm{C}$ as required by SAE J300 \& CEC L-105 (figure 6).

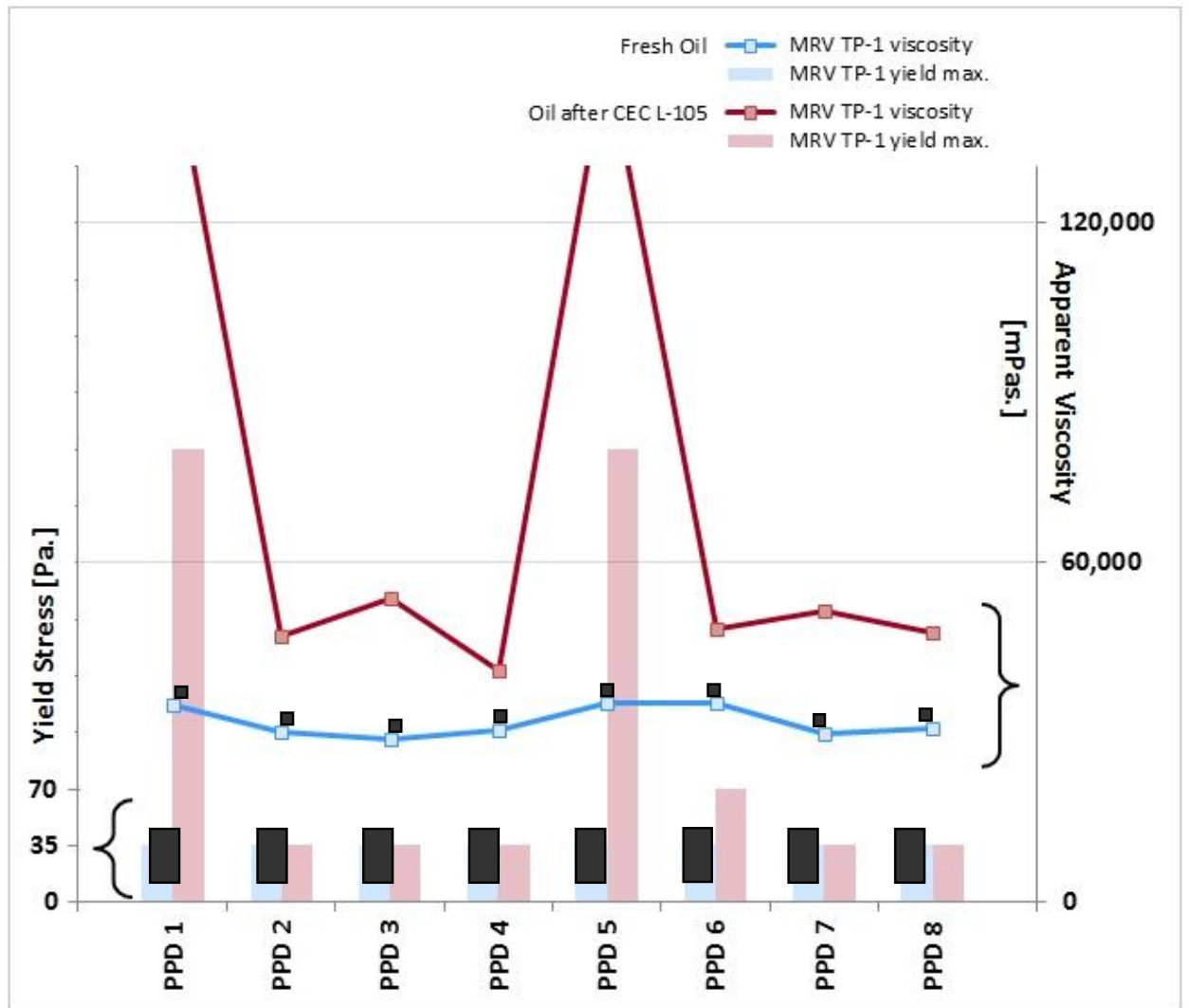

Figure 6: PPD at $0.3 \%$ in a $5 \mathrm{~W}-30$ engine oil before and after CEC L-105 aging

The dark symbols and bars respectively show the MRVTP-1 Viscosity and Yield Stress for the fresh oil treated with eight different commercial PAMA type PPDs. All results are a pass (Apparent Viscosity $\leq 60000 \mathrm{mPas}$, Yield $\leq 35 \mathrm{~Pa}$ ). The bright symbols and bars are for the same oil and PPDs after aging by CEC L-105. Here only 5 of the 8 PPDs are giving pumpability passes, and even in the passing tests the MRV TP-1 Viscosity is much increased.

These results show that subjecting an oil to CEC L-105 oxidation can strongly influence it's PPD appetite. A PPD found fully suitable for the fresh oil may no longer be acceptable on the aged oil, even at increased treat rate. In such cases a more careful selection of the PPD type is required, but often a PPD can be identified which will allow the aged oil to pass at reasonable PPD treat rate. 


\section{Conclusions}

Over time additional cold flow testing requirements have been added to engine oils, most recently the need to meet MRV TP-1 pumpability after CEC L-105 aging. Each addition requirement has tended to narrow the range of acceptable PPDs so today the selection of a suitable PPD is increasingly challenging.

In most cases aging an oil by CEC L-105 worsens the MRV TP-1 performance, often dramatically so. In these cases the number of PPDs capable of achieving an MRV TP-1 pass in the aged oils is lowered compared to the fresh oil, and greater care and effort is required in selecting a suitable PPD. A PPD found fully suitable for the fresh oil may no longer be acceptable on the aged oil, even at increased treat rate.

The worsening of low temperature performance in oils aged in an engine or in bench tests like ROBO or CEC L-105 is due to changes in the oxidised oil such as reduced solvency, and in addition for CEC L-105 the introduction of new wax species. The PPD is not degraded by the ageing process.

Engine oils based on PAMA and COMB type VII are much less influenced in terms of MRV TP-1 by CEC L-105 aging. The number of acceptable PPD options is much wider for oils including these VII types and PPD selection much less challenging. Although based only on a small data set of two package types, package also an influence on PPD choice and CEC L-105 response. This shows that a PPD choice found to work alongside one package type cannot be assumed to be acceptable if the package is changed.

\section{References}

[1] Selby, T.W., "A Comparison of the Effects of Cranking Speed and Oil Viscosity on Low-Temperature Engine Starting", SAE Progress in Technology, Volume 10, pp. 11-14,1966. Originally presented in SAE Paper 805C, Jan. 13-17, 1964.

[2] Shaub, H., "A History of ASTM Accomplishments in Low Temperature Engine Oil Rheology: 1966-1991," ASTM STP 1143, Low Temperature Lubricant Rheology Measurement and Relevance to Engine Operation, Ed. R.B. Rhodes, pp. 1-19,1992. [3] M.F. Smith, Jr and J.P.Graham, "Pumpability of Multigrade Engine Oils at Low Temperatures", SAE Trans. Vol. 80 (1971), Paper No. 710139.

[4] R.M. Stewart and C.R. Spohn, "Some Factors Affecting the Cold Pumpability of Crankcase Oils", SAE Trans. Vol. 81 (1972), paper 720150.

[5] M.L. McMillan and C.K. Murphy, "The Relationship of Low-Temperature Rheology to Engine Oil Pumpability", SAE Paper 730478, published in SAE SP-382, "Viscosity and Its Application to Automotive Lubricants" SAE 1973.

[6] K.O. Henderson, R.E. Manning, C.J. May, R.B. Rhodes, "New Mini-Rotary Viscometer Temperature Profiles That Predict Engine Oil Pumpability", SAE Paper No. 850443.

[7] R.L. Stambaugh, "Engine Oil Viscosity Classification Task Force - Low Temperature Report", SAE Meeting Minutes Attachment, June 1981. 
Selection of pour point depressants...

[8] Stambaugh R.L., O'Mara J.H., "Low Temperature Flow Properties of Engine Oils", SAE Paper No. 820509.

[9] ASTM D 4684, "Standard Test Method for Determination of Yield Stress and Apparent Viscosity of Engine Oils at Low Temperature", ASTM Book of Standards. Volume 05.02, March 2013. Petroleum Products and Lubricants (II): D3711-D6122. [10] Bartko M.A., Florkowski D.W., Devlin M.T., Shoutian L., Eggerding D.W., Lam W.Y., McDonnell T.F., Tze-Chi J., "Low Temperature Rheological Properties of Aged Crankcase Oils", SAE Paper 2000-01-2943.

[11] International Lubricant Standardization and Approval Committee. ILSAC GF-4 STANDARD FOR PASSENGER CAR ENGINE OILS. January 14, 2004. http://www.inp.nsk.su/news/seminars/2011_298_ILSAC.pdf

[12] Kinker, B., Romaszewski, R., and Souchik, J., "Pour Point Depressant Robustness after Severe Use in Passenger Car Engines in the Field and in the Sequence IIIGA Engine", SAE Technical Paper 2005-01-2174, 2005. [13] Kinker, B.G., Romaszewski, R.A., and Palmer, P.A., "ROBO - A Bench Procedure to Replace Sequence IIIGA Engine Test", Journal of ASTM International (JAI), Vol. 4, No. 10, 2007, Paper ID JAI 100916.

http://www.astm.org/DIGITAL_LIBRARY/JOURNALS/JAI/PAGES/JAl100916.htm [14] International Lubricant Standardization and Approval Committee. ILSAC GF-5 Standard for Passenger Car Engine Oils. December 22, 2009.

http://www.gf-5.com/uploads/File/ILSAC_GF-5_Dec-22-09_final.pdf

\section{Authors}

Phil Hutchinson, Evonik Oil Additives, Darmstadt, Germany Joan Souchik, Evonik Oil Additives, Horsham, Pennsylvania, USA Aileen Flanagan, Evonik Oil Additives, Horsham, Pennsylvania, USA Dmitriy Shakhvorostov, Evonik Oil Additives, Darmstadt, Germany

\section{Received}

10.10.2013.

\section{Accepted}

27.2.2014. 